\title{
Die verhouding tussen Kolossense en Efesiërs as ' $n$ sinoptiese probleem
}

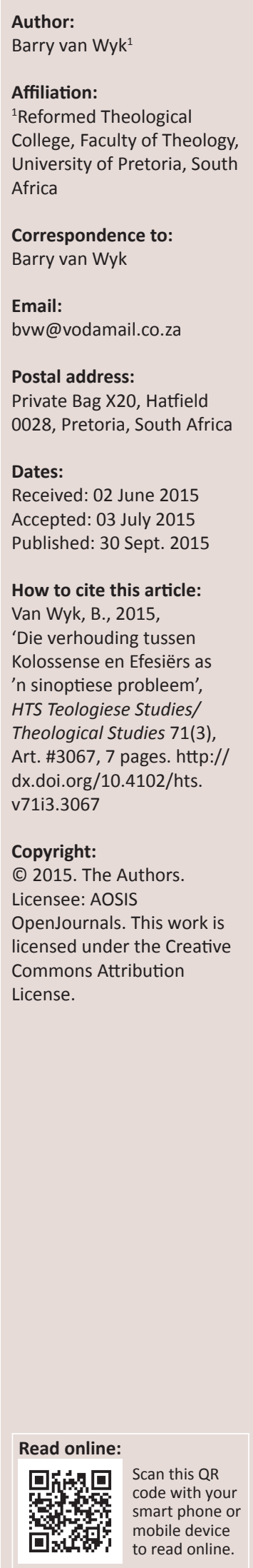

The relationship between Colossians and Ephesians as a synoptic problem. Research by different scholars concluded that some letters traditionally ascribed to Paul were probably not written by him and drew a distinction between Pauline and Deutero-Pauline letters. The majority of scholars nowadays are of the opinion that the letters to the Colossians and the Ephesians are Deutero-Pauline and that Ephesians, at least, was surely not written by Paul. The results of research on the synoptic problem can be used and applied to the two letters under discussion because a comparison shows that there are striking similarities between the two. The most recent research shows that Ephesians made use of the letter to the Colossians but not without redactional changes to suit the author's literary purpose. This method is exegetically known as redaction-criticism, linked to the social-science viewpoint that the author of the letter to the Ephesians acted as a change agent on behalf of a change agency.

\section{Inleidend}

Die wyse waarop die Bybel as Woord van God benader word, is van wesenlike betekenis vir die omgang met asook die verstaan van die Skrif. Die wêreld waarin die Skrif die lig gesien het, is histories verwyderd van die huidige konteks en moet derhalwe eers in dié verband verstaan word alvorens van die Skrif na die huidige konteks tot gestaltegewing van die Reformatoriese aksioma 'sola scriptura' beweeg word.

Dit is tipies van die sogenaamde Hervormde teologie in Suid-Afrika om krities na die Bybel te kyk, en hierdie kritiese blik vind veral in die verstaan van die kerk en die gebruik van die Bybel uiting. Krities na die Bybel kyk beteken om die Bybel binne konteks te verstaan en om te aanvaar dat die kulture en ontstaanswêreld van die Bybel anders daar uitsien as wat ons vandag ken. Dit het al dikwels tot kritiek gelei wat veral as liberaal getipeer is aangesien gemeen word dat die Bybel op hierdie manier beheer en bevraagteken word (Van Aarde 2013:11). Davies (2011:4-9) verwoord iets daarvan wanneer hy stel dat die Bybel, met besondere verwysing na die Nuwe Testament, analities hanteer moet word. Die Bybel, en by implikasie ook die Nuwe Testament, is 'n versameling van verskillende briewe en dele wat die indruk laat dat die Nuwe Testament eerder as ' $n$ biblioteek beskou moet word. ' $n$ Analitiese benadering is nie daarop uit om te bewys dat die Bybel waar of vals is nie, maar is eerder '... in great part, the study of the process through which the New Testament came into being' (Davies 2011:5).

'n Bruikbare voorbeeld in dié verband is die navorsing wat met betrekking tot die evangelies Matteus, Markus en Lukas gedoen is. Dié waarneming dat daar tussen dié drie evangelies 'n besondere verband bestaan, het daarop uitgeloop dat navorsers die drie evangelies naas mekaar en in onderlinge verband bestudeer. Die drie genoemde evangelies vertoon 'n merkwaardige ooreenkoms wat tot gevolg gehad het dat na die drie as die sinoptiese evangelies verwys word. Dit kom volgens die Griekse begrip daarop neer dat die drie evangelies saam beskou word. Dit het daartoe aanleiding gegee dat na die sinoptiese probleem verwys word. In dié verband is grondliggende werk deur verskeie navorsers gedoen (kyk na Perrin 1974:3-6; Telford 2014:152). In hierdie navorsing is die Markus-evangelie as uitgangspunt gebruik en het die siening ontwikkel dat Markus die oudste van die drie genoemde evangelies is en dat sowel Matteus as Lukas tot 'n groot mate van Markus gebruik gemaak het. In die lig van die ooreenkoms tussen dié drie genoemde evangelies is ook navorsing oor die sogenaamde Q-bron gedoen as verteenwoordigend van 'n ouer vorm van die Jesus-tradisie (kyk na Miller 2010:257-278; Telford 2014:150).

Na literêre kritiek en vormkritiek het 'n derde eksegetiese benadering die lig gesien, naamlik redaksiekritiek. Die term redaksiekrititek is 'n vertaling van die Duitse woord Redaktionsgeschichte 
waarvan Marxsen (1956) die skepper was (Telford 2014:153). Perrin (1974) verduidelik dit soos volg:

It is concerned with studying the theological motivation of an author as this is revealed in the collection, arrangement, editing, and modification of traditional material, and in the composition of new material or the creation of new forms within the traditions of early Christianity. (bl. 1)

In die Duitse woord klink die begrip redakteur, maar dié benadering is terselfdertyd meer as redaksionele werk aangesien die skrywer sy stof onderwerp aan kreatiewe redaksionele werk in die sin van skeppende transformasie wat deur moderne navorsers raakgesien en bestudeer word. Kernagtig gesien, fokus redaksiekritiek volgens Telford (2014) op die volgende:

\begin{abstract}
... the way an author or editor, in this case the evangelist, has adapted ('redacted') earlier materials to his own theological ends. ... Redaction is the conscious reworking of older materials in such a way as to meet new needs. (bl. 151)
\end{abstract}

Hayes en Holladay (2007:127) definieer die taak van redaksiekritiek soos volg: '[R]edaction critics are interested in how a given story or tradition has undergone changes in its transmission history to reach its final stage' en voeg 'n verdere definisie by (Hayes \& Holladay 2007; kyk ook na Telford 2014:149-153):
... a type of biblical criticism that explores how an author's theology is reflected in changes that the author makes to previous material. Since these changes are usually made to literary materials, they are editorial in nature. 'Redaction' and 'redactional' are technical terms used to describe such editorial changes. (p. 127)

Die woord Redaktionsgeschichte word in Engels weergegee met 'compositional analysis' (Combrink 2009:366) waaruit die Afrikaanse weergawe komposisie-analise afgelei word.

Naas die komposisie-analise het ook die sosiale konteks waarin ' $n$ bepaalde Skrifgedeelte tot stand gekom het vir die eksegese van kritiese belang geword. Die afbreek van die skeidingsmuur wat in die Efesiërbrief ter sprake kom, is vir die lesers van deurslaggewende belang. Die sosiale agtergrond van die skeiding en die gevolge daarvan vir Jood en heiden bied insiggewende materiaal om die volledige impak van die skrywer se uitspraak beter te verstaan (kyk na Ubieta 2001:260-280).

Steeds vanuit die sosiale konteks kan die skrywer van die Efesiërbrief, veral gesien in die lig daarvan dat hy uit Kolossense put maar terselfdertyd met sy kerkbegrip en Christologie veel verder gaan, beskou word as 'n sosiale meningsvormer (change agent) wat deur ' $n$ alternatiewe staat van bewussyn (alternate state of consciousness) bedryf word en in belang van sy opdraggewer (change agency) optree. Malina en Pilch (2013) verwoord dit soos volg:

Thus the change agent functions as a communication link between two or more social entities: the change agency responsible for the innovation and those to and for whom the innovation is directed. (bl. 235)
In die Nuwe Testament kan die apostels as gestuurdes as sodanige meningsvormers beskou word om die koninkryk van God te verkondig in die Naam van Jesus Christus (change agency) wat uit die dood opgewek is. In die lig van Malina se mening pas ' $n$ dissipel in die rol van 'n meningsvormer as iemand wat op grond van 'n sending verandering in die gemeenskap wil bewerkstellig. Dit is van toepassing op die skrywer van die Efesiërbrief wat as meningsvormer optree met die oog daarop om sy lesers tot nuwe insigte te bring.

Hierdie artikel probeer derhalwe aantoon dat die twee onderhawige briewe saam beskou moet word in die lig van die resultate wat met die drie sinoptiese evangelies bereik is en as 'n sinoptiese probleem bekend staan. Komposisieanalise as eksegetiese metode lig die ontwikkeling en groei uit wat tussen Kolossense en Efesiërs plaasvind. Sommige geleerdes is inderdaad die mening toegedaan dat die skrywer as sosiale meningsvormer gesien kan word wat die gegewens van Kolossense redaksioneel aanpas om sy doel te bereik. Daar word gebruik gemaak van bepaalde aspekte wat in beide briewe voorkom maar in Efesiërs verder uitgebou word. Ek argumenteer dan waarom Efesiërs en Kolossense naas mekaar en in verhouding tot mekaar beskou moet word.

\section{Kolossense en Efesiërs}

Navorsing oor die 13 briewe in die Nuwe Testament wat tradisioneel aan die apostel Paulus toegeskryf word, het verrassende resultate na vore gebring. Aan die hand van navorsing het die mening met verloop van tyd ontstaan dat slegs sewe briewe, naamlik Romeine, 1 en 2 Korintiërs, Galasiërs, Filippense, 1 Tessalonisense en Filemon aan Paulus toegeskryf kan word, terwyl die res as Deutero-Paulinies beskou word. Verder is die outeurskap van Kolossense en 2 Tessalonisense onseker, terwyl Efesiërs en die pastorale briewe, 1 en 2 Timoteus asook Titus, aan die generasie ná Paulus toegeskryf word (Dunn 2009:99). Die debat oor die outeurskap van die briewe duur al dekades lank en word deur verskillende navorsers verskillend beantwoord - en daar is steeds nie eenstemmigheid nie (Collins 1988:136; Wright 2003:236).

Ooreenkomste tussen die twee tekste het daartoe gelei dat die oorwig geleerdes die mening toegedaan is dat Efesiërs literêr van Kolossense afhanklik is (kyk na Duling 2003:272; Talbert 2007:4). Verder word bepaalde temas in Efesiërs ook anders ontwikkel as in Kolossense. Dit het gelei tot die vermoede dat die skrywer van Efesiërs iemand anders as die outeur van Kolossense was (Collins 1988:144).

In die debat oor die verhouding tussen die twee briewe is die opmerking gemaak dat dit eintlik ' $n$ sinoptiese probleem is wat daarop neerkom dat, soos met die drie sinoptiese evangelies, die twee briewe ook gesamentlik beskou moet word:

The form in which Ephesians has been handed down is the nub of the problematic relationship between Ephesians and Colossians. In many respects, that relationship can be considered as a minor synoptic problem. (Collins 1988:134) 


\section{Kolossense}

Die outeurskap van Kolossense asook die verhouding tussen Efesiërs en Kolossense is óók die onderwerp van navorsing, soos reeds gemeld. Die debat het gehandel oor die vraag of Kolossense van Efesiërs afhanklik was of andersom. $\mathrm{Na}$ aanleiding daarvan word deesdae aanvaar dat Efesiërs van Kolossense gebruik gemaak het (Dunn 2009:1107; Foulkes 2002:27).

Naas argumente van taal en styl is dit veral die teologiese opbou wat die aandag trek. Die skrywer maak in die begin van die brief gebruik van 'n himne wat waarskynlik reeds bestaan het maar deur hom aangepas is om vir sy Christologie diensbaar te wees. Käsemann (soos aangehaal deur Lohse) en Lohse is van oortuiging dat die woorde 'van die kerk'

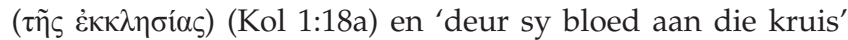

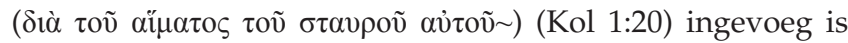
aangesien die Christelike betekenis van die lied daarsonder weinig invloed sou oorhou (Collins 1988:191; Lohse 1971:45). Die inhoud van die himne toon 'n verhewe styl en inkleding wat van die res van die brief asook van die teologiese inhoud daarvan verskil. Hoewel Christus nie pertinent genoem word nie, is daar geen twyfel dat die himne oor Christus handel nie

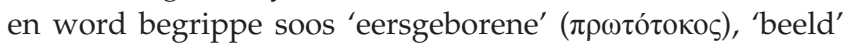

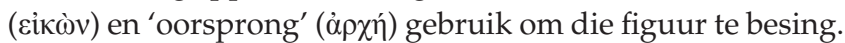
Van Aarde (s.a.) verduidelik dit soos volg:

Deur met die plasing van die himne in die huidige konteks die figuur in die himne met Christus te identifiseer, het die outeur hierdie kosmiese dimensies op Christus oorgedra en sodoende van Hom 'n kosmiese figuur gemaak waardeur met die toevoeging van die kerk, ook 'n kosmiese dimensie aan die kerk verleen is. (bl. 3)

Die Christologie wat in Kolossense 1:15-23 ter sprake kom, verwoord 'n ontwikkeling wat verder strek as dit wat in enige van die egte briewe aangetref word. Christus is hier die beeld van die onsigbare God (Kol 1:15), die eersgeborene van die hele skepping, wat as ware verteenwoordiger van God bekend maak wat onsigbaar was. Hy is nou die eersgeborene, nie net onder gelowiges nie maar van die hele skepping. Christus is nou die doel van die hele skepping, alle dinge is deur Hom en vir Hom geskape en dit beteken dat alles aan Hom onderworpe is (Kol 1:16). Dit is ' $n$ tipiese kosmiese beklemtoning wat nie in die egte briewe voorkom nie. Die kosmiese element word ook aan die kerk verbind (Kol 1:18, 24; 2:19; 3:15) waarvan Christus die hoof is. In die himne (Kol 1:15-20) kom 'n opvallende verskil met betrekking tot die Christologie in teenstelling met die egte briewe voor. Die himne beklemtoon dat alles deur Hom geskape en in Hom versoen is. Die Christologie wat in die himne ter sprake kom, voorsien derhalwe 'n bruikbare argument vir die vermaning dat alles in die Naam van die Here Jesus moet gebeur (Kol 3:17).

Verder toon die Christologie van die skrywer 'n soteriologiese karakter wat veral in Kolossense 2:9-15 as tweede Christologiese uitspraak duidelik word. Besonder opvallend is die uitspraak dat in Hom die volle wese van God immers liggaamlik teenwoordig is (Kol 2:9), wat herinner aan Kolossense 1:19. As die volheid van God in Hom woon, kom dit daarop neer dat Christene wat Jesus Christus as Heer ontvang het in Hom leef en deur Hom vervul is (Kol 2:10). Christene deel in die Christus-gebeure deur die doop waardeur hulle begrawe en opgewek is (Kol 2:12). Dit het veral aan die kruis gebeur toe Hy die skuldbrief van die sonde verwyder het (Kol 2:14). In Kolossense 3:1-4 word die Griekse woord vir Christus vier keer met die lidwoord geskryf, kenmerkend van die skrywer, omdat Christus gesien word as Middelaar van die verlossing en dit verbaas derhalwe nie dat die titel 25 keer in die brief gebruik word nie (Collins 1988:190-197).

In beide briewe kom 'n besondere kerkbegrip na vore in die sin dat van die een kerk gepraat word wat nie net die gemeente is waar die ontvangers van die brief gewoon het nie. Die kerk is hier universeel van aard en funksioneer as ' $n$ kosmiese grootheid, soos MacDonald (2008) dit stel:

Colossians holds out an image of the cosmic Christ. Explicitly equated with the church (Col 1: 18-24), 'the body' is also ruled by its head, Christ $(1: 18 ; 2: 10,19)$. But the church and the cosmos merge to a certain extent in Colossians - the church becomes a spiritual and cosmic assembly transcending earthly problems and disputes. (bl. 15)

Die outeur van Kolossense beklemtoon Christus se kosmiese aktiwiteite soos sy betrokkenheid by die skepping, by die versoening van die kosmos en die onderwerping van die kosmiese magte (Kol 1:15-20; 2:15). Die kerk verstaan sigself as 'n grootheid waarin die wêreldheerskappy van Christus erken en as werklikheid ervaar word. Die outeur sien homself as dienaar van die kerk (Kol 1:24-25) as die instansie wat heil bewerk (Pelser 1995:660-661). Lohse (1971; kyk ook na Patzia 2011:32) verwoord dit soos volg:

The author of Col, however, proceeds to interpret this mythological statement in such a way that the concept 'body'

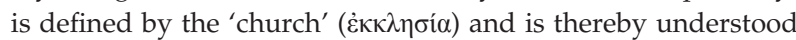
as a historical entity. Here and now the exalted Lord exercises his rule over all the world as the head of his body which is the church. (bl. 55)

Wanneer die lesers die kerk met die liggaam van Christus identifiseer, ontvang hulle daardeur'n besondere status. 'The ecclesiology expressed here closely identifies the church with Christ, and indeed, connects them so closely that it is difficult to envision a more intimate relationship' (Sumney 2008:2033).

In die brief aan die Kolossense kom ook 'n huistafel (Kol 3:18-4: 1) voor wat veel meer beknop as die een in Efesiërs is. Lohse (1971:154) is van mening dat die huistafel nie regtig met die geheel verband hou nie. MacDonald toon egter aan dat die huistafel 'n geïntegreerde deel van die boodskap van die brief en die standpunt teenoor die valse onderrig uitmaak. Die literatuur van die antieke wêreld vorm die agtergrond van huistafels, en indien die huistafel met byvoorbeeld die gedagtegang van Aristoteles vergelyk word, kom die temas regeer en regeer word na vore. Huistafels was voordelig vir die breëre sosiale realiteit in gemeenskappe. Beide briewe 
beklemtoon die betekenis van Christus as heerser oor die kosmos en belig die identiteit van gelowiges as diegene wat daardeur regeer word. Die gewaarwording ontstaan ook dat die skrywer versigtig was oor die indruk wat gelowiges op ongelowiges laat (Kol 4:5-6), asook oor spanning wat tussen vroeë Christelike gemeenskappe en die buitewêreld ontstaan het, soos wanneer vroue en slawe in nie-Christelike huise tot bekering kom (1 Tim 6:1-2; 1 Pet 3:1-6) (MacDonald 2008:160-162).

Gelowiges is om die volgende redes aangeraai om aan 'n nie-gelowige paterfamilias onderdanig te wees: ' $[A]$ desire to limit the potentially controversial visibility of these members and a recognition of their strategic opportunities to evangelize nonbelievers within the home' (MacDonald 2008:162). Dit is opvallend dat die huistafel in Kolossense meer aandag skenk aan die situasie van slawe as aan die ander partye wat genoem word (Kol 3:22-25). Sowel slawe as heersers word herinner aan die verskil tussen menslike heersers en die Here in die hemel. Beide dien dieselfde Here en is aan straf en finale oordeel blootgestel. Die paterfamilias was 'n heer van die huishouding, maar terselfdertyd ook leier van die huiskerk wat in die huishouding ontstaan het (1 Tim 3:1-7). Nuwe navorsing (kyk na MacDonald 2008:163-165) vestig die aandag op die problematiek en omstandighede waaraan slawe onderwerp is in die lig van seksuele misbruik, prostitusie en weiering wat sou kon lei tot die ontdekking van 'n keuse wat vir die Christendom gemaak is (kyk na Kol 3:5).

Die klaarblyklike aanvaarding van slawerny is vir moderne lesers onbegryplik. Daar moet egter nie uit die oog verloor word nie dat geleentheid vir sosiale hervorming nie bestaan het soos vir hedendaagse mense nie. Daar is spanning tussen simboliek wat vra dat alle sosiale standaarde en voorkeure van die gemeenskap verwerp moet word en huishoudelike standaarde wat die eise van die gemeenskap beklemtoon. 'n Boodskap van bemagtiging klink in die doop-beeldspraak, die aflegging van die vleeslike liggaam (Kol 2:11), die kansellering van die skuldbrief (Kol 2:14) en die ontwapening van die owerhede en magte gevolg deur hulle openbare vernedering as gevangenes (Kol 2:15). Vir die slawe van die gemeenskap moes dit bemoedigend gewees het en tekenend van 'n dubbele gewete: enersyds as totale bevrydes in godsdienstige konteks, maar andersyds in die sosiale lewe nog steeds slawe. Die moontlikheid bestaan dat dít die manier was waarop gelowiges as slawe in 'n vyandige sosiale samelewing oorleef het. Die heerskap van Christus en die belofte van erfgenaam wees, asook die vertroosting dat almal ongeag sosiale stand voor God gelyk is, moes veral vir slawe besonder vertroostend geklink het. Kaelber (1987:442) noem dit 'n innerlike askese wat nie op fisiese dissipline nie maar op geestelike dissipline neerkom. Dit verg nie noodwendig enige afstand doen van bepaalde wêreldlike vreugdes nie, 'but rather detachment from or renunciation of the world per se' (Kaelber 1987). Eenvoudig gestel, beteken dit om in die wêreld te wees maar nie van die wêreld nie. Innerlike askese was in direkte konflik met die valse leraars wat onder die indruk was dat die heil in sigbare tekens van weerstand teen die sosiale orde gevind moes word (Kol 2:8, 18). In die brief skemer 'n poging deur om 'n Christelike lewe te lei wat onderskeibaar maar nie buite die sosiale konteks funksioneer nie.

Nimfa (Kol 4:15) se naam word genoem as 'n vroulike leier van 'n huiskerk binne 'n sosiale gemeenskap wat in die brief deur'n huistafel opgeroep word om mans te gehoorsaam (Kol $3: 18)$. Die verstaan daarvan hou verband met die onderskeid tussen mag (power) en gesag (authority). Eersgenoemde is die moontlikheid om gehoorsaamheid af te dwing, terwyl laasgenoemde gesien word as die erkenning dat iets reg is. 'Thus the authority granted to the paterfamilias in Col 3: 18-4: 1 is an example of "culturally recognized authority"' (MacDonald 2008:168). Dit verteenwoordig die erkenning dat die mag wat aan die paterfamilias in die gemeenskap gegee is '... at large is also right within the context of the early church'(MacDonald 2008).

Dit is dus moontlik dat dusdanige gesag ook aan vroue gegee is, veral binne die Christelike sosiale konteks. Die gesag waarmee 'n paterfamilias in sosiale konteks opgetree het, soos in die huistafel verwoord word, hou ook 'n indirekte erkenning in van die mag van vroue om hulle mans tot die Christendom te bekeer en sodoende die kerk uit te brei. 'n Huistafel skep die indruk van 'n vreedsame gesin in harmonie met die paterfamilias as gesinshoof. Die situasie was waarskynlik heel anders wanneer Christene hulle in 'n huishouding bevind het waar die paterfamilias nie 'n gelowige was nie. Huistafels is 'n etiese ideaal wat nie die volle historiese werklikheid weergee nie en moet dus gesien word in die lig van 'n ontwakende Christendom in kompetisie met ander sosiale groepe in 'n vyandige wêreld (MacDonald 2008:163-169).

\section{Efesiërs}

Dit is problematies dat die plekaanduiding in sommige manuskripte ontbreek. Dit het aanleiding gegee tot die vermoede dat die brief moontlik 'n omsendskrywe was wat vir verskillende gemeentes bedoel was (Collins 1988:140; MacDonald 2008:17; Patzia 2011:146), veral as 'n mens dit saamlees met die feit dat die brief ook geen persoonlike groeteboodskappe bevat nie.

Die styl van die Efesiërbrief is retories en stadig bewegend in teenstelling met die egte briewe. Die outeur gebruik lang sinne (Ef 1:15-23; 4:11-16) en 'n vraagteken kom slegs aan die einde van Efesiërs 4:9 voor. Hy maak gebruik van 'n opstapeling van sinonieme asook kenmerkende genitiewe konstruksies. Die brief bevat 2425 woorde wat 'n totale woordeskat van 529 woorde verteenwoordig. Hiervan kom 42 woorde slegs in Efesiërs in die Nuwe Testament voor, terwyl 36 ander woorde elders in die Nuwe Testament aangetref word, maar nie in die ander Paulusbriewe nie. Die brief vertoon ooreenkomste in taal en styl met die Qumrantekste, en Semitiese sintaksis kom vier maal meer in die brief voor as in die ander Paulus-briewe. 
Aan die Universiteit van Marburg het Werner Ochel reeds in 1934 'n proefskrif verdedig wat meen dat 'n sogenaamde navolger van Paulus die brief na die voorbeeld van Kolossense gekomponeer het. Die outeur het 'n himne (Ef 1:3-14) saam met tradisionele liturgiese (Ef 1:19-2:10) asook vermanende materiaal (Ef 3:2-7; 5:22-6:9) bygevoeg. Navorsers wys daarop dat meer as 'n derde van die 155 verse in Efesiërs parallel is aan Kolossense, in sowel volgorde as inhoud. Van die mees opvallende parallelle is tussen Efesiërs 3:2 en Kolossense 1:25-26, Efesiërs 4:15-16 en Kolossense 2:19, Efesiërs 4:22-24 en Kolossense 3:9-10, Efesiërs 5:22-6:9 en Kolossense 3:18-4:1 asook Efesiërs 6:21-22 en Kolossense 4:7-8 (kyk ook na Duling 2003:272 verv.; MacDonald 2008:4 verv.; Talbert 2007:4-5). Verder is daar verse in Efesiërs wat die indruk skep van 'n samevloeiing met tekste uit Kolossense: Efesiërs 1:7 (Kol 1:13, 14, 20), Efesiërs 1:19-20 (Kol 1:11; 2:12), Efesiërs 3:2-13 (Kol 1:24-29) (Collins 1988:143-144).

Behalwe styl en woordeskat is die teologiese inhoud van die brief bepalend vir die argument teen Pauliniese outeurskap. Hy gebruik die woord misterie ( $\mu v \sigma \tau$ ṕ van die misterie van Christus wat vir hom die kern van die evangelie uitmaak. Die misterie is aan hom geopenbaar (Ef 3:3) en bestaan daarin dat Jood en heiden gesamentlik erfgename is van die evangelie in Christus Jesus. Dit is God se plan vir die verlossing wat in Jesus Christus plaasgevind het (Ef 1:9-10). Die misterie verwoord nie net die eenheid van Jood en heiden in een liggaam van Christus nie, maar ook die versoening van alles in Christus (Ef 2:16).

Die kerk is die besondere tema in die brief en daarom is die opmerking al gemaak dat die Christologie van die brief vanuit die ekklesiologie verstaan moet word (Collins 1988:147; Pelser 1995:661). Die skrywer gebruik die woord

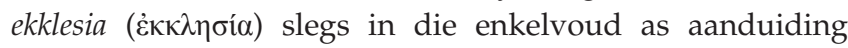
van die universele kerk. In Romeine en Korintiërs word die liggaam waarvan Christus die hoof is, gebruik as aanduiding van die verskillende lede met besondere verwysing na die geestelike gawes. Hier is dit die universele kerk wat as liggaam van Christus beskou word (Ef 4:1-16) en Christus is die hoof van dié liggaam (Duling 2003:278-279).

Jesus se hoofskap word in die volgende uitspraak bevestig: 'Hy het alles onder sy voete gestel en Hy het Hom as Hoof

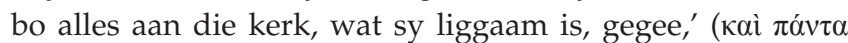

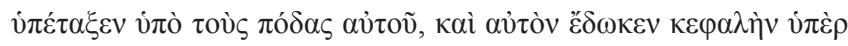

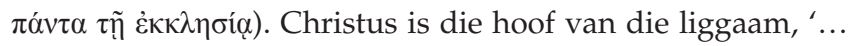
a description which points to his authority over the church and his lifegiving role in its regard... The universal church is the body, but Christ is the head' (Collins 1988:147).

Navorsers is van mening dat die Christologie in die Efesiërbrief van die rykste en mees ontwikkelde in die Nuwe Testament is na aanleiding van die teologiese, kosmologiese en antropologiese verbande wat daarin voorkom (Collins 1988:153). Dié drieledige verband kom veral in die openingsgebed (Ef 1:3-14) na vore, eerstens met 'Lofwaardig

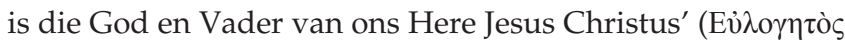

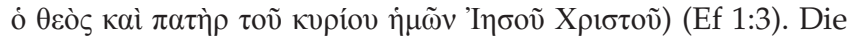
formule Vader van ons Here Jesus Christus kom ook in vier ander verbande voor (Ef 1:17; 3:11; 5:20 en 6:24) met die uitsondering dat die verwysing na Vader in een (Ef 3:1) weggelaat word. Dit hou waarskynlik verband met die formule in Christus ( $\dot{\varepsilon} v$

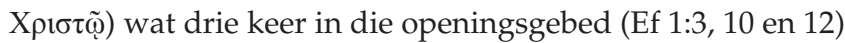
en verder in nege ander gedeeltes van die brief (Ef 1:1, 20;2:6, $7,10,13 ; 3: 6,11,21 ; 4: 32)$ gebruik word. Deur die formule en die herhaling daarvan te gebruik, presiseer die skrywer sy Christologie binne die openingsgebed (berakah) as 'n literêre vorm en verbind die Vader en die Here Jesus Christus aan mekaar. Daardeur word die teologiese verband van sy Christologie onderstreep deur die Vader as '... a relational title, as divine epithet. The God to be praised is the Father or our Lord Jesus Christ' (Collins 1988:154).

Die kosmologiese verband van sy ekklesiologie in die openingsgebed blyk wanneer beklemtoon word dat die lesers reeds voor die skepping van die wêreld ( $\pi \rho$ ò $\kappa \alpha \tau \alpha \beta 0 \lambda \tilde{\eta} \varsigma$

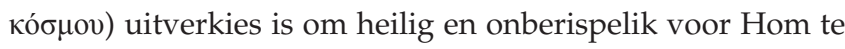
wees (Ef 1:4) (Collins 1988:155).

Dit is God wat ons geseën (Ef 1:3), gekies (Ef 1:4), voorbestem (Ef 1:5) en die misterie van sy wil bekend gemaak het (Ef 1:9). Dit alles het in Christus as die middelaar van die verlossing gebeur en verwoord die hoogtepunt van die antropologiese verband van sy Christologie. 'Eph 1:22 serves as the focal point of what Neyrey calls the author's headship christology' (Collins 1988:158). Die benaming Heer (кúpıৎ) as voorkeur Christologiese titel word 26 keer

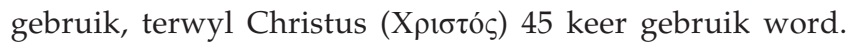
Die vermanende (paraenetiese) karakter van die brief word reeds in die eerste hoofstuk beklemtoon met die vooruitsig dat die lesers heilig en onberispelik in liefde voor Hom sal

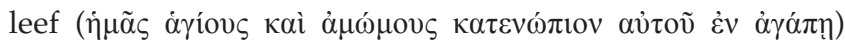
(Ef 1:4). Dit is opvallend dat daar in die eerste drie hoofstukke slegs een imperatief gebruik word (Ef 2:11), terwyl 36 werkwoorde in die laaste drie hoofstukke in die imperatief gestel word. Dit word ondersteun deur die feit dat 20 van die 26 keer wat die titel Heer gebruik word in die laaste drie hoofstukke voorkom.

Die brief het ook 'n redelik omlynde huistafel (Ef 5:21-6:9) wat oor jare veral aandag getrek het na aanleiding van die verhouding tussen man en vrou en die manier waarop dié verhouding 'n gelykenis van die verhouding tussen Christus en sy kerk word (Ef 5:22-33). Die aandag aan die huwelik as metafoor vir die verhouding tussen Christus en die kerk is terselfdertyd die onderskeidende element van die huistafel in die Efesiërbrief. Dit is betekenisvol dat die huistafel hier volg op die voorgaande en verbind word met die paraenetiese gedeelte (Ef 4:17-6:9) as 'n oproep aan gelowiges (Ef 4:17) om deur hulle lewenswyse uiting te gee aan die nuwe bedeling wat deur Christus 'n werklikheid geword het. Die literêre agtergrond van die Nuwe-Testamentiese huistafels is geleë in 'n poging om die huistafels aan die welwese van die owerheid te bind waar die gesin as 'n mikrokosmos van die owerheid beskou is. Daarom was dit nie verbasend dat 
die etiek en respek vir die owerheid in die Nuwe Testament vanuit huistafels gemotiveer is nie (1 Tim 2:1-7; Tit 3:1-11; 1 Pet 2:13-14). 'Household relations are understood as reflecting a wider social reality: the obedience of wife to husband is viewed as a reflection of the obedience of church to Christ' (MacDonald 2008:337; Patzia 2011:266-275; kyk ook na Talbert 2007:136144).

\section{Kolossense en Efesiërs: Sosiaal en komposisie-analities beskou}

Die wyse waarop die skrywer van Efesiërs van Kolossense gebruik gemaak het, en veral die verdere ontwikkeling met betrekking tot die egte Paulus-briewe, laat die indruk dat hy inderdaad tot ' $n$ groot mate sy eie klemtone geplaas het en as 'n sosiale meningsvormer beskou kan word. Die verandering moet nie net teen die inhoud van die egte Paulus-briewe gesien word nie, maar veral teenoor die Jodedom soos verwoord in die denkbeelde van die Fariseërs, geskoei op die Pentateug en uiteindelik geformuleer in die Mishna (220 n.C.) en die Talmoed (600 n.C.) (Davies 2011:30-31). Malina en Pilch (2013:235-238) se siening oor ' $n$ meningsvormer (change agent) se manier van doen is bruikbaar en van toepassing op die skrywer van die Efesiërbrief met betrekking tot Kolossense en Paulus, maar lewer hedendaags tegelykertyd terugskouend ook die appèl tot verandering en koersaanpassing aan die destydse Jodedom sónder Christus, om hulle na die Christendom as kerk ván Jesus Christus waarvan $\mathrm{Hy}$ die Heer is, te wend. Dit verklaar die noodsaak om te verander, want dit wat Jesus gedoen het, maak mense wat vanweë die sonde dood is, lewend (Ef 2:1, 4,5) en breek al die ou geykte gewoontes en grense af sodat mense in die lig van die evangelie een nuwe mensheid (Ef 2:14-16) kan wees. Ontvangers van die evangelie kan nie onaangeraak bly nie en sodoende skep die skrywer as 'n meningsvormer (change agent) die nodigheid vir verandering. Die motivering tot verandering word (sosiaal gesien) deur 'n ander instansie (change agency) teweeggebring, soos in die aanhef van die Efesiërs gestel word, naamlik 'n apostelskap deur die wil van God (Ef 1:1).

Verder vermeld Collins (1988:143) dat die verhouding tussen Kolossense en Efesiërs as 'n sinoptiese probleem beskou word en vanuit die oogpunt van die komposisie-analise hanteer word. Die ooreenkomste tussen die twee briewe, met besondere verwysing na die mate waarin die skrywer van Efesiërs van Kolossense gebruik gemaak het, verklaar waarom die twee briewe saam beskou moet word soos die drie evangelies sinopties bestudeer word.

Wanneer Kolossense en Efesiërs met mekaar vergelyk en saam (sinopties) gelees word, is dit voor die hand liggend om beide briewe gesamentlik te beskou (kyk na MacDonald 2008:4-6; Talbert 2007:3), juis vanweë die onderlinge verband tussen hulle asook die feit dat die skrywer van Efesiërs van Kolossense gebruik gemaak, maar dit tog aangepas en uitgebrei het. Kolossense is ' $n$ brief aan een gemeente met bepaalde probleme, soos filosofieë wat vir die gemeente 'n bedreiging is en allerlei kosmiese beginsels wat sommige gemeentelede noodsaaklik ag. Die boodskap van die skrywer is dat hulle vrese misplaas is en sy gerusstelling word gemotiveer deur die himne (Kol 1:15-20) wat vooraan geplaas is en aandui waarom die gemeente nie hoef te vrees of bedreig hoef te voel nie.

Die Christologie van Kolossense is hoofsaaklik saamgevat in die himne en die mening bestaan dat sy Christologie hoofsaaklik soteriologies (Kol 3:17) van aard is en as die uitgangspunt van sy bemoedigende getuienis aan lidmate dien (Kol 2:9-15) (Collins 1988:193). Daarteenoor word gestel dat die Christologie van Efesiërs die mees ontwikkelde en rykste Christologie in die Nuwe Testament is. Dit veral omdat, soos aangedui, die Christologie van Efesiërs 'n teologiese, kosmologiese en antropologiese korrelaat vertoon. Die Christologiese klem word deur sy menigvuldige gebruik van die titel Here (26x) asook die gebruik van Christus (45x) bevestig (Collins 1988:153, 159).

Dit is egter veral in die ekklesiologie wat die onderskeid opvallend na vore kom deurdat dit swaarder in die Efesiërbrief as in Kolossense beklemtoon word. Die swaarder klem is duidelik wanneer die volgende twee tekste uit die twee briewe met mekaar vergelyk word:

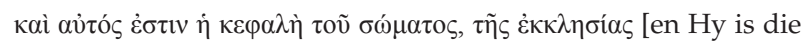
Hoof van die liggaam van die kerk] (Kol 1:18)

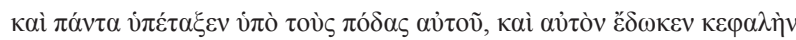

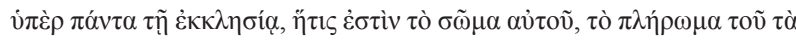

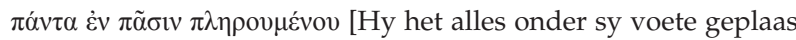
en Hom gegee as Hoof oor alles aan die kerk, wat sy liggaam is, die volheid van alles wat in alles vervul word] (Ef 1:22, 23)

Neyrey het opgemerk dat Efesiërs 1:22 as die fokuspunt van die outeur se hoofskap-Christologie dien (Collins 1988:158). Efesiërs se outeur dui aan dat die kerk nie tot een kerk (gemeente) op 'n bepaalde plek beperk is nie. Dit is universeel, kosmologies, deel van die een heilige, algemene kerk wat op verskillende plekke steeds deel van die een kerk vorm (Patzia 2011:125, 141). Daarom het navorsers reeds aangedui dat die sentrale tema van Efesiërs die kerk is (Bultmann 1961:182; Dunn 2009:1121; Pelser 1995:661; Van Aarde 2005:27). Behalwe dat die kerk liggaam van Christus is, vorm die kerk ook die volheid van Hom wat alles in almal

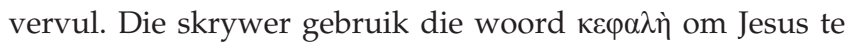
beklemtoon as die Hoof oor alles en almal en derhalwe ook oor die kerk. Hy is die Hoof oor die hele wêreld en derhalwe oor die totale kerk.

Die totale kerk bestaan nou uit Grieke en Jode omdat die skeiding oorwin is en die verdeeldheid daarmee opgehef is. Die middelmuur van skeiding wat afgebreek is (Ubieta 2001:276), verwoord 'n bepalende vooruitsig van groei na Christus toe as die Hoof waarvan die Gees die waarborg vorm van die volheid wat op dié wyse bereik moet word. Die Gees maak die groei na Christus toe moontlik en die omgee vir mekaar bestaan in die diakonie wat tussen gelowiges ter sprake moet kom (Ef 4:12). Gelowiges groei nie net van onder 
na bo nie, maar ook van bo na onder, waarvan die Gees as waarborg ( $\dot{\rho} \rho \alpha \beta \omega \dot{\omega})$ geld. Die veelvuldige vermelding van die Gees in Efesiërs is van besondere betekenis (MacDonald 2008:212-214) en dui op 'n redaksionele uitbreiding in vergelyking met Kolossense waar die Gees slegs 'n enkele keer genoem word (Kol 1:8).

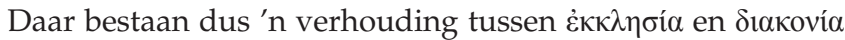
as die gemeenskap wat in die kerk posvat as ' $n$ roepende en bemoedigende uitdaging in die lig van die Gees as $\alpha \rho \rho \alpha \beta \omega ́ v$. Christus is die Hoof van die kerk, maar dit word anders as by Kolossense verder uitgebrei in die sin dat die kerk die volheid van Christus is (Ef 1:23) wat uit Hom en tot Hom groei as Hoof van die kerk (Ef 4:15-16). Die kerk in Efesiërs groei sowel uit Christus as na Hom toe, sodat die kerk uiteindelik so volwasse sal wees soos 'n volgroeide mens, soos Christus is.

Die plaaslike kerk in Efesiërs word as't ware geïgnoreer ten gunste van die universele kerk. Sy visie van die kerk is een (Ef 4:4), heilig (Ef 5:26-27), algemeen (Ef 1:22-23) en apostoliese kerk wat wesenlik ' $n$ hemelse verskynsel geword het omdat gelowiges reeds in die hemel is (Ef 2:6). Die kerk is hemels maar ook aards in die sin dat gelowiges aangemoedig word om nie langer soos heidene met leë gedagtes te leef nie (Ef 4:17). Die feit dat die kerk op die apostels en die profete gebou is, bevestig dat die kerk ook aards is (Ef 2:20). Die kerk is hier 'n tydlose grootheid en in die lig van wat oor gelowiges gesê word (Ef 4:23-24 en 5:8), ontstaan die indruk dat die hede van die gelowiges reeds anderkant die einde (eschaton) lê. Daar is nie sprake van 'n nabye wederkoms nie, maar gelowiges word opgeroep om hulle voor te berei op 'n uitgerekte bestaanstryd in die wêreld en om in lewenskwaliteit te groei.

Die kerk as liggaam van Christus en Christus as Hoof van die liggaam is sentrale beelde van die kerk in dié geskrif, soos ook die voorstelling van die kerk as bouwerk. Die kerk word nie net beskou as liggaam van Christus en wat dit wesenlik beteken nie, maar die beeld word ook gebruik om die groei van die kerk te beskryf. Die kerk is volgens die beeld 'n groeiende gebeure wat na die Hoof toe groei. Die liggaam bewerk sy eie groei deur die aandeel van elke lid (Ef 4:16). Die vooruitgang en ontwikkeling van die liggaam word ook in die vooruitsig gestel met die doelwit om soos 'n volwasse man tot eenheid van geloof te kom, tot kennis van die Seun van God, sodat die mate van wasdom van die volheid van Christus bereik kan word (Ef 4:13). Die gebeure rondom die kerk en Christus as Hoof van die liggaam laat gelowiges nie vry in 'n lugleegte nie, maar plaas hulle onder die appèl om, terwyl hulle in liefde aan die waarheid vashou, in alle opsigte na Hom toe te groei (Ef 4:15).

\section{Slotopmerkings}

Die outeursvraagstuk met betrekking tot beide briewe sal waarskynlik 'n bron van navorsing en debat bly waaroor verskil van mening sal bly bestaan. Die meeste navorsers is van mening dat ten minste Efesiërs nie deur Paulus geskryf is nie (MacDonald 2008:16). Ongeag die debat oor outeurskap is dit onontwykbaar dat daar tussen die twee briewe 'n opvallende ooreenkoms bestaan en dat die skrywer van Efesiërs heel waarskynlik van Kolossense gebruik gemaak en dit verder aangepas het. Hierin kom die sosiale model van 'n meningsvormer, as iemand wat op grond van hoër gesag deur 'n alternatiewe staat van bewussyn gedryf word, handig te pas. Verder is dit ook bruikbaar om vanweë die ooreenkomste maar ook die verskil in uitbreiding en redaksionele herskepping die verhouding tussen Kolossense en Efesiërs as 'n sinoptiese probleem te beskou, wat beteken dat die een nie sonder die ander gelees en voluit waardeer kan word nie.

\section{Erkenning Mededingende belange}

Die outeur verklaar hiermee dat hy geen finansiële of persoonlike verbintenis het met enige party wat hom nadelig of voordelig kon beïnvloed het in die skryf van hierdie artikel nie.

\section{Literatuurverwysings}

Bultmann, R., 1961, Theologie des Neuen Testaments, 4. Aufl, Mohr, Tübingen. Collins, R.F., 1988, Letters that Paul did not write, Michael Glazier, Delaware.

Combrink, B., 2009, 'Redaction criticism', in A. du Toit (ed.), Focusing on the message, pp. 341-380, Protea, Pretoria.

Davies, S.L., 2011, The New Testament: An analytical approach, Polebridge, Belmont, TN.

Duling, D.C., 2003, The New Testament history, literature, and social context, Wadsworth, Belmont, TN.

Dunn, J.D.G., 2009, Beginning from Jerusalem, Eerdmans, Grand Rapids, MI.

Foulkes, F., 2002, Ephesians, Eerdmans, Grand Rapids, MI.

Hayes, J.H. \& Holladay, C.R., 2007, Biblical exegesis, John Knox, Westminster. (Kindle edn.).

Kaelber, W.O., 1987, s.v. 'Ascetism', in M. Eliade (ed.), The encyclopedia of religion, MacMillan, New York, NY, pp. 441-445.

Lohse, E., 1971, Colossians and Philemon, Fortress, Philadelphia, PA.

MacDonald, M.Y., 2008, Colossians and Ephesians, Liturgical, Minnesota, MN.

Malina, B.J. \& Pilch, J.J., 2013, Social-science commentary on the Deutero-Pauline letters, Fortress, Minneapolis, MN.

Marxsen, W., 1956, Der Evangelist Markus, Vandenhoeck \& Ruprecht, Göttingen.

Miller, R.J. (ed.), 2010, The complete Gospels, 4th edn., Polebridge, Oregon.

Patzia, A.G., 2011, Ephesians, Colossians, Philemon, Baker Books, Grand Rapids, MN.

Pelser, G.M.M., 1995, 'Die kerk in die Nuwe Testament', HTS Teologiese Studies/ Theological Studies 51(3), 645-676. http://dx.doi.org/10.4102/hts.v51i3.1421

Perrin, N., 1974, What is redaction criticism?, SPCK, London.

Sumney, J.L., 2008, Colossians: A commentary, Westminster-John Knox, London. (Kindle edn.).

Talbert, C.H., 2007, Ephesians and Colossians, Baker Academic, Grand Rapids, MI.

Telford, W.R., 2014, The New Testament: A beginner's guide, Oneworld, London.

Ubieta, C.B., 2001, “'Neither zenoi nor paroikoi, sympolitai and oikeioi tou theou” (Eph 2:19): Pauline Christian communities: Defining a new territoriality', in J. Pilch (ed.), Social scientific models for interpreting the Bible: Essays by the Context Group in honor of Bruce J Malina, pp. 260-280, Atlanta, GA. (Society of Biblical Literature).

Van Aarde, A.G., s.a., Die teologie van die Deutero-Pauliniese briewe, Studie-eenheid 8: Kolossense, Universiteit van Pretoria, Pretoria.

Van Aarde, A.G., 2005, Inleiding tot en teologie van die Deutero- en post-Pauliniese Briewe, NTW Universiteit van Pretoria, Pretoria. ([BTh] 452, Studiegids).

Van Aarde, A.G., 2013, "n Postliberale perspektief op 'n ekklesiologiese modaliteit as 'n ecclesiola in ecclesia: Heroriëntasie in die Nederduitsch Hervormde Kerk van Afrika', HTS Teologiese Studies/Theological Studies 69(1), Art \#2012, 41 bladsye. http://dx.doi.org/10.4102/hts.v69i1.2012

Wright, N.T., 2003, The resurrection of the Son of God, SPCK, London. (Kindle edn.). 